\title{
Impact of Organizational Inertia and Dynamic Capabilities on Educational Performance of the Charitable Societies and Its Impact on Mathematical Performance of Elementary At-Risk Students
}

\author{
Parvaneh Amiripour ${ }^{1}$ (D), John A. Dossey² (D) Ahmad Shahvarani ${ }^{3}$ (D) \\ ${ }^{1}$ Department of Mathematics, Science and Research Branch, Islamic Azad University, Tehran, Iran \\ Parvaneh.Amiripour@gmail.com $\}$ \\ ${ }^{2}$ Distinguished Professor of Mathematics Emeritus, Illinois State University, USA \\ \{jossey@|llinoisState.edu\} \\ ${ }^{3}$ Department of Mathematics, Science and Research Branch, Islamic Azad University, Tehran, Iran \\ \{Maths Ahmad@yahoo.com\} \\ Received on 24 June 2016; revised on 1 September 2016; accepted on 1 September 2016; published on 15 January 2017 \\ DOI: 10.7821/naer.2017.1.199

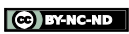

\begin{abstract}
This study is an adjunct to a research effort focused on a mathematical curricular innovation in four non-governmental schools in Tehran, Iran. This study queried balanced, random sample of 100 educational personnel from the schools concerning dynamic capabilities associated with change (sensing opportunities, seizing opportunities, and reconfiguring assets) and issues surrounding organizational inertia (finding resources, confronting path dependency in change, and establishing new processes). Additional data collected described the personnel's perceptions about innovations and new processes instituted in their schools. Student performance data from the prior year's final mathematical examination were also gathered. The data describe a portion of the educational change potential of the schools, including improved student achievement. The variables informed by all of the data were evaluated by multivariate methods. The findings showed that beliefs about dynamic capabilities had a significant positive impact on educational performance and that educational performance had a positive impact on the final mathematical exam scores. The results also indicate that the organizational inertia of the schools had a significant negative impact on the educational performance of the schools. Conclusions were formed based on the analysis of the defining factors of the variables mentioned above and recommendations given for implementing change are proposed.
\end{abstract}

KEYWORDS: MATHEMATICS EDUCATION, PRIMARY EDUCATION, EDUCATIONAL PERFORMANCE, NONGOVERNMENTAL ORGANIZATIONS, ORGANIZATIONAL CHANGE

\footnotetext{
*To whom correspondence should be addressed:
}

Science \& Research Branch, Hesarak, Tehran, I. R. Iran; 1477893855 (Department of Mathematics, Basic Sciences)

\section{INTRODUCTION}

"Inertia is the strong persistence of existing structure, capability. For an organization's survival or success, it may be good or bad to maintain strong persistence" (Wernerfelt, 1984, p. 173). In a stable environment and conditions, the phenomenon of inertia provides an organization with the sense of stability (Hannan \& Freeman, 1984). When the capacity of an organization becomes rigid, many successful organizations fail to note it, even in the face of perceived external threat or opportunity, or to take action (Sull, 1999; Gilbert, 2005, 2006). In this study, the researchers examine the impact of organizational inertia on educational professionals teaching in a set of schools tasked with the education of an at-risk population of primary school students in Tehran, Iran. These students were Afghan students in NGO formed schools and taught by instructors with little or no background in teaching at the grade levels. Further, research shows that having mere contact with the students is insufficient to create the positive experience to provide instruction in a milieu that matches students' interest and backgrounds (Morales, Sanhueza, Friz, \& Riquelme, 2017). Experience in the present student indicates that education personnel's belief is key in shifting students' inertia. The results of the entire study are found in Amiripour, Dossey, Shahvarani, \& Tabibi (2016).

Developing a program for at-risk students through merging approaches chronicled in prior studies (Sullivan, Tobias, \& McDonough, 2006; Vatter, 1992) suggested that a new approach could either bring success or stress to students' mathematics learning. At-risk students whose learning is negatively perturbed may suffer an increased probability of dropping out of school (Johnson, 1998), suffering academic failure, or having an increased absence rate (Bakar et al., 2010; Sudarshan \& Maung Aye, 2008). However, other studies suggest that the merging of global patterns of instruction with predetermined goals, focused instruction, and a high degree of program structure combined with clear and focused counseling heighten their success (Lewis, 2014; Powell et al., 2015; Wehlage \& Rutter, 1986). Most 
researchers in the field agree that such expectations are determinants affecting positive changes in at-risk student's growth in learning (Tosun, 2000). The results of the mathematics education study showed that the students receiving instruction in solving mathematical problems based on whole number arithmetic in the experimental sections performed significantly higher than students receiving instruction based on the traditional methods found in classroom textbooks following the Iranian school curriculum and taught by widely practiced instructional methods. The instructional approaches used in the study square with the research findings dealing with overcoming inertia-related obstacles in organizations (Liao, 2002; Liao et al., 2008).

Central to the present study is finding a way to assist at-risk students in recognizing and altering an inertia that impedes correct learning processes while implementing the experimental schema-based problem pattern (PP) approach to problem solving. This approach provides students with a way of building concrete representations for whole number mathematical word problems and using these representations to separate data, units, and operations and then sequence them visually to build a path to the problem solution (Amiripour, Dossey, Shahvarani, Tabibi, 2016). This approach, and similar approaches indicate that they have the basis for creating successful programs that can alter students' approach to mathematical problem solving in primary grades (Carpenter, Fennema, Franke, Levi, \& Empson, 2014; Dyson, Jordan, Beliakoff, \& Hassinger-Da, 2015; Fagnant \& Vlassis, 2013). Altering inertia requires a focus on students' cognitive models of representations for problems and conceptual sequencing of actions with the solving of those problems (Carpenter et al., 2014).

This altering of students' inertia also involves dealing with the inertia in the educational personnel of the school itself. This is the major focus of this portion of the larger study. We examine the beliefs and other reports of the teachers, counselors, and other staff that were involved in educational decision-making relative to the at-risk students involved. To start, we examine the literature on organizational change in inertia and its components.

\subsection{Indicators of Dynamic Capabilities}

The dynamic capabilities framework introduced by Teece (2007) is based on the observations that "effective application of dynamic capabilities is the function of the presence of three ingredients: sensing of new opportunities multiplied by seizing ability (effective decision making) and multiplied by the proper (order) of implementation" (p. 1329). It is these dynamic capabilities that we use to focus on change in the mathematical education of at-risk primary students.

\subsubsection{Sensing Opportunities}

At the heart of change is the filtering and shaping of ideas for constructing new technologies, approaches, or methods to confront learning issues in mathematics classes. Schools, and then the professionals that teach within them, have to collect and identify the main information from knowledge sources in order to change. Teece (2007) argues that organizations are ubiquitous examples of such organizations, must create procedures to keep "the winds of change" alive within their walls. "Individual and organizational traits of sensing capabilities can be processes to select new technologies, to tap the developments in exogenous science and technologies, to identify suppliers' innovations, changing needs and innovation” (p. 1330).

\subsubsection{Seizing Opportunities}

Seizing can be viewed as "strategic decision skills and execution.” Once a new leader or path to a problem's solution is sensed, it must be identified, evolved and tested. Well-known organizations have identified solution paths along with models for testing and determining what needed personnel, supplies, and distribution plans exist to model innovations and to ferret out the advantages they bring. To access transformative changes, an "organization should demonstrate leadership, communicate effectively, and recognize non-economic factors, values, organization culture" (Teece, 2007, p. 1330). Successful organizations that consistently view their context from multiple perspectives, have a deeper comprehension of user needs and are able to bring solutions to people at the point they recognize that they need them.

\subsubsection{Reconfiguration/Transformation}

A key element of the identification of resources and investment opportunities is the capacity to "recombine and to reconfigure assets" as changes or opportunities evolve. An important managerial function is the "redesign of routines.” Educational personnel's capacity to identify, improve, develop, and use the combination of assets is a considerable "dynamic capability." The capability of school leadership to identify requests and opportunities to invest is fundamental to dynamic capabilities.

Teece's (2007) notion is "the disaggregation of dynamic capabilities into sensing, seizing and organizational transformation elements transcending ordinary capabilities. To avoid chaos in organizations these components should be implemented in subsequent or simultaneous manner, as routines and rules in the organization would likely be in a continuous state of flux" (Teece, 2007, p. 1341). These three important components of the "dynamic capabilities" framework empower an organization to reform and create tangible and intangible changes in their capabilities to achieve increased performance. A school's leaders must act as a group to implement all of the component elements of dynamic capabilities simultaneously. Teece's (2007) “dynamic capabilities framework is a most salient one because it most deeply disaggregates the dynamic capabilities into constituent parts -sensing, seizing and reconfiguring- enabling the understanding of micro-foundations of dynamic capabilities” (p. 1332). The furthering of students' dynamic capabilities requires schools and teachers understand and practice the components of sensing, seizing, and reconfiguring to implement new curricula and problem solving skills.

\subsection{Indicators of Organizational Inertia}

\subsubsection{Resources and Process}

Teece, Pisano and Shuen defined strategic advantage as a function of organizational processes, positions, and paths about dynamic capabilities. "What it [the organization] can do and where it [the organization] can go is thus heavily constrained by the typology of its processes, positions, and paths” (Teece et al., 1997, p. 529). Teece et al. laid out organizational and managerial processes and defined them as: "coordination and integration, learning, and reconfiguration.” Productive systems indicate "high interdependency and that it may not be possible to change one level without changing others" (p. 529). On the other hand, "learning is a process by which repetition and experimentation enable tasks to be performed better and quicker and new 
production opportunities to be identified" (Teece et al., 1997, p. 529). Gilbert (2005) notes there are two kinds of organizational inertia: "resource rigidity" and "routine rigidity." It is important to recognize how they differ and differentiate between them. "External threat can motivate resource commitment, but routines can remain locked in the traditional business model" Gilbert (2005) argued. He added, "threat decreases resource rigidity but increases routine rigidity in a predictable, and repeated pattern. Subtypes of inertia move in different directions (as a result of) their underlying causal mechanism shaving differing tasks" (p. 755). However, it seems whatever resource inertia promotes or controls, routine rigidity will be modified.

\subsubsection{Path Dependency}

Path dependences, according to Teece et al. (1997) are "defined as a function of...current position and the paths ahead” (p. 530). An organization's current position is formed by the way that it has traveled. Sydow et al. (2009) cited path dependency as one of the most important components of inertia concepts in an organization. As a function, path dependence depends to a greater extent on what has most recently happened, then the outcome of selecting from choices, and, finally, a lock in phase where the choice becomes more inflexible and well protected.

\subsection{Dynamic Capabilities and Their Relationships with the Performance of Organizations}

Why do organizations with the same goals perform differently? The relationship between dynamic capabilities and organizational performance is indirect. One of the largest administrative challenges of any organization is how to manage its dynamic capabilities to get superior performance. Organization performance can be measured via two variables: product innovation rate and process innovation rate. Drnevich \& Kriauciunas (2011) measured positive and negative aspects of dynamic capabilities related to organizational performance. The impacts of dynamic capabilities are measured at two levels: a) process; and b) organization. While these two levels produce different results, their heterogeneity has a positive effect to the organizational performance at process level, not just at the organization level. Zott (2003), as well as Drnevich and Kriauciunas (2011), argue that dynamic capabilities are the levers for considerable competitive advantages and for achieving superior organizational performance. Zahra, Sapienza, and Davidsson (2006) argue that dynamic capabilities influence both operational capabilities and organizational knowledge and the indirect impact of these on organizational performance. Therefore, the possession of dynamic capabilities alone cannot contribute to superior organizational performance. Dynamic capabilities must be managed and applied at the appropriate time in order to produce superior organizational performance. Fletcher \& Harris (2012) found that "sensing and seizing capabilities were most important during market entry, commercialization and growth stage of new venture internationalization. Reconfiguration was associated with growth, stability and profitability stage” (p. 24). Since dynamic capabilities indicators are "interdependent and are not discrete," they overlap and combine during different organization development steps in order to improve organization performance. Much the same is expected in an educational setting.

\subsection{Organizational Inertia and Its Relationship with Performance of Organization}

The affects that inertia has on an organization can take on different forms: it can account for weak to minimal performances in cases involving "inability to adopt," it can minimize risk/problems or account for efficient decisionmaking, or it can contribute to leadership styles that focus on the development of the organization (Miller \& Chen, 1994). Dobrev, Kim and Carroll (2003) indicated that the inertia of organizations especially contributes to their failure when transformations occur. Therefore, studies on the effects that inertia has on organizations tended to emphasize findings related to organizational structure and the outside environment/constraint dynamics inertia have on an organization.

\section{METHODS AND MATERIALS}

\subsection{Hypotheses and Conceptual Model}

The study seeks information and other data to test the three hypotheses dealing with education personnel beliefs:

- Hypothesis I: Dynamic capabilities have a positive impact on educational performance of the Child Houses.

- Hypothesis II: Organizational inertia of Child Houses has a negative impact on educational performance of the Child Houses.

- Hypothesis III: Educational performance of Child Houses has a positive impact on Final Mathematics Examination (FME) of at-risk students.

For hypotheses I through III the researchers used the conceptual model in Figure 1 as a guide. As shown, the analysis approach factored in the impact of educational performance in Child Houses where the students were educated and the students' performances on the Final Mathematics Examination (FME) from the previous year, as a photo of mathematical life in the schools. The model, that was based on Nedzinskas' doctoral thesis proposal (2013), describes the impact of organizational inertia and dynamic capabilities on educational performance. The changes also took into account the administrative structures at the Child Houses involved.

\subsection{Participants}

In the study, the population from which samples were chosen consisted of students and educational personnel from Child Houses of two non-governmental, charitable societies providing aid to at-risk families in Iran: the Society for Protecting the Rights of the Child (SPRC) and the Association of Protection of Child Labour (APCL). Both societies have the same main social welfare foci, structural features, and procedures and strive to support the objectives of the United Nations' Human Right Commission's Committee on the Rights of the Childs' Convention (United Nations, 2016). 


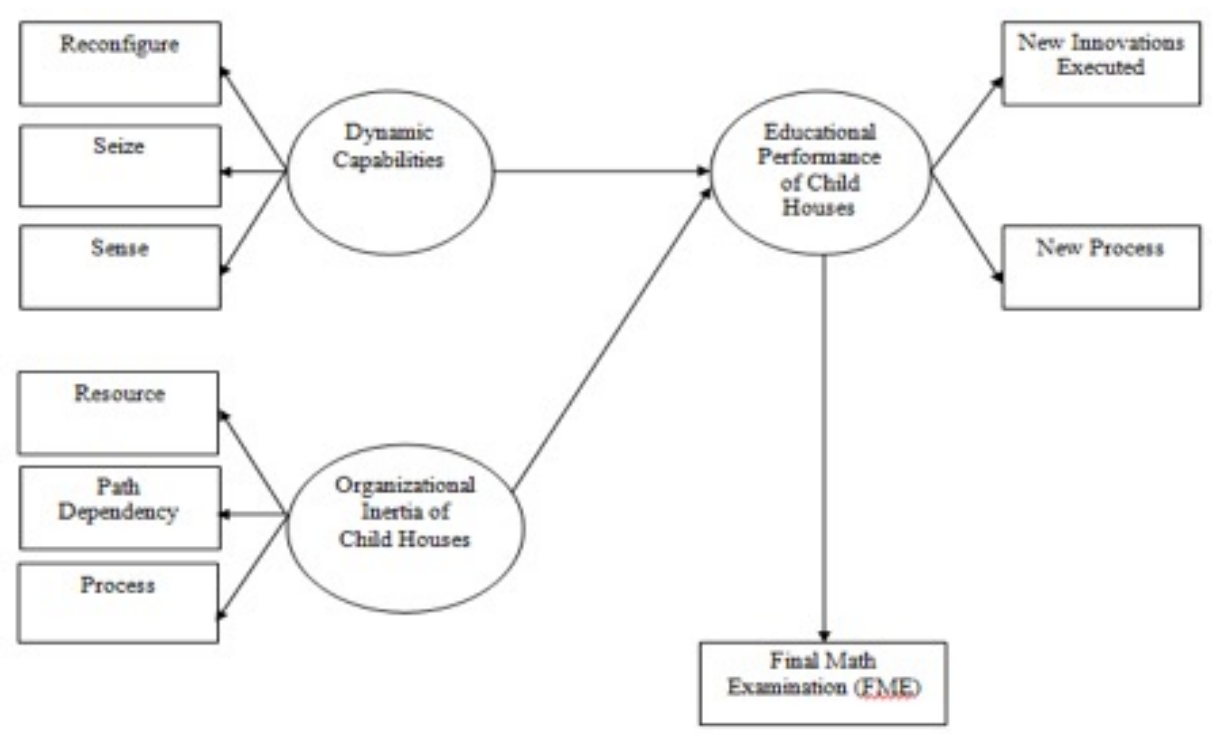

Figure 1. Research Conceptual Model adapted from Nedzinskas (2013)

In particular, the study worked with the Nasar Khosrow and Shosh houses from the SPRC and the Molavi and Khavaran houses from the APCL, both in southern Tehran. Both provide, among their many programs, educational, cultural, and social development initiatives for families and students escaping the war-torn areas of Afghanistan. The at-risk students all are involved in menial or laboring work outside school hours, even at the primary grades level. It is from these populations that the at-risk students selected for the study were extracted. The SPRC provides such services to students from grades kindergarten through three. The APCL provides similar services to students from kindergarten through fifth grade level. The students and educational personnel selected to participate in a larger study were drawn from students in grades two and three and the personnel working with these students. The Nasar Khosrow and Shosh Houses contain a population of 150-170 at-risk students with 90 educational personnel serving them. Fifty of the personnel and 40 of the students were chosen as participants for the larger study and this special portion of it. The Molavi and Khavaran Houses of the APCL serve 150-200 grades-1-to-5 students and 95 educational personnel. From these, 50 educational personnel and 60 at risk students were selected for the study. The selections were made using cluster sampling (probability-random between groups and non-probability purposive sampling within groups). This resulted in 100 educational personnel and 100 at-risk students from grade 2 (35 students) and grade 3 (65 students). The only participation of the students, who were volunteers in the instructional program in the global study, amounted, here, only to the use of their final mathematics examination (FME) scores as a measure of school achievement. The education personnel ${ }^{\mathrm{i}}$ completed a questionnaire and consisted of teachers, aids, psychologists, social workers, and educational authorities.

\subsection{Questionnaire}

A questionnaire administered (Amiripour et al., 2016) to the educational personnel was modified from Nedzinskas' dissertation's focus on business to focus on educational change. The questionnaire has two sections: the first a few demographical items; and the second with the study focus items.
The items were presented as situations that could occur in their Child Houses. The personnel had to respond to a statement about a proposed course of action based on five point Likert scale: “strongly disagree,” “disagree,” “neutral,” “agree,” and "strongly agree." There were 32 items on the main scale based on the main variables: reconfigure, seize, and sense for the "dynamic capabilities variable"; resource, path dependency, and process for the "organizational inertia variable"; and new innovations executed and new processes developed for "educational performance of Child Houses variable.” Before the distribution of the questionnaire, the first researcher read all items aloud to the educational personnel. They were instructed to view the items in the context of supposing how they would to solve a future educational crisis in their respective Child House. They should select to rate the statement with the response indicating how they agreed with the use of the course of action described in making the particular decision required for the future. The final pieces of data came from FME. ${ }^{\text {ii }}$ The exam has 20 questions. This result in 10 scores for numerical and diagram questions and another 10 scores for word problem solving and more general problem solving. Together they provide 20 possible score points. This examination was administrated in the Child Houses the previous spring at the close of the school year.

\subsection{Validity and Reliability}

A panel of university and elementary teachers agreed that the FME and questionnaire have face and content validity. In addition, analyses of Convergent and Divergent validity coefficients were computed with regard to factor loadings and average variances (AVE) extracted with respect to construct validity, respectively. An EFA (Exploratory Factor Analysis) is estimated for the Divergent validity. Structural equation modeling (SEM) can be used to estimate AVE can by examining the factor loadings through Confirmatory Factor Analysis (CFA) (Segars, 1997). These loadings, which represent the path, should be above 0.50, ideally above 0.70 (Chin, 1998; Hair, Tatham, Anderson, \& Black, 1998; Segars, 1997). The Discriminate validity is computed using values for AVE and $\mathrm{R}^{2}$. Hence, both qualitative and quantitative approaches to measuring validity suggest that the questionnaire and examination are suitable for use. The reliability of the FME and questionnaire were measured by Cronbach's $\alpha$ for internal consistency reliability (1951). The values of Cronbach's $\alpha$ for grades 2 and 3 were 0.80 and 0.81 , respectively. These values support the usage of FME and 
questionnaire as reliable measures for research. Through the SmartPLS (Partial Least Square) software, Cronbach's $\alpha$ was calculated for each latent variable, which consists of the remaining observed variables. Composite reliability (CR) is computed by squaring the sum of loadings and then dividing the sum by the sum of squared loadings plus the sum of error terms (Werts, Linn, \& Joreskog, 1974). The values of these composite reliability measures were higher than 0.70 .

\section{DATA ANALYSIS \& RESULTS}

\subsection{Descriptive Statistical Analyses}

The data in Table 1 provide a sketch of the gender, age, educational attainment, and experiences of the educational personnel.

Table 1. Descriptive statistics for educational personnel

\begin{tabular}{|c|c|c|c|c|}
\hline Gender & \multicolumn{2}{|c|}{ Female } & \multicolumn{2}{|c|}{ Male } \\
\hline $\mathbf{N}$ & \multicolumn{2}{|c|}{80} & \multicolumn{2}{|c|}{20} \\
\hline Age & $\begin{array}{c}\text { 20-30 years } \\
\text { old }\end{array}$ & $\begin{array}{c}\text { 31-40 years } \\
\text { old }\end{array}$ & $\begin{array}{c}41-50 \\
\text { years } \\
\text { old }\end{array}$ & $\begin{array}{c}51 \text { years } \\
\text { or more } \\
\text { old }\end{array}$ \\
\hline $\mathbf{N}$ & 60 & 28 & 10 & 2 \\
\hline $\begin{array}{l}\text { Academic } \\
\text { Certificate }\end{array}$ & $\begin{array}{c}\text { M. A. } \\
\text { (Associate of } \\
\text { Science) }\end{array}$ & $\begin{array}{c}\text { B. C. (Licenciate } \\
\text { degree) }\end{array}$ & Mas & $\begin{array}{l}\text { r's ans } \\
\text { ove }\end{array}$ \\
\hline $\mathbf{N}$ & 10 & 54 & & 6 \\
\hline $\begin{array}{l}\text { Having Edu- } \\
\text { cational } \\
\text { Experiences }\end{array}$ & 5 yeas or less & $\begin{array}{l}\text { Between } 6 \text { and } \\
11 \text { years inclu- } \\
\text { sive }\end{array}$ & 12 ye & or more \\
\hline $\mathbf{N}$ & 55 & 40 & & 5 \\
\hline
\end{tabular}

The data indicate that the number of female educational personnel $(\mathrm{N}=80)$ is greater than the number of males $(\mathrm{N}=20)$ and most personnel were relatively young, in the age range of 20 to 30 years old. The majority of educational personnel had earned a B.C. $(\mathrm{N}=54)$ as their highest form of certification. The majority of personnel had five years or less of experience $(\mathrm{N}=$ $55)$.

Table 2. Frequencies for gender in the control and experimental groups

\begin{tabular}{cccccc}
\hline & \multicolumn{2}{c}{$\begin{array}{c}\text { Control (SPRC \& } \\
\text { APCL) }\end{array}$} & \multicolumn{2}{c}{ Experiment (SPRC \& APCL) } \\
\hline Grade & $2^{\text {nd }}$ Grade & $3^{\text {rd }}$ Grade & $\begin{array}{c}2^{\text {nd }} \\
\text { Grade }\end{array}$ & \multicolumn{2}{c}{$3^{\text {rd }}$ Grade } \\
\hline $\mathrm{N}$ & 20 & 30 & 15 & \multicolumn{2}{c}{35} \\
\hline Age & $\begin{array}{c}9 \text { years } \\
\text { old }\end{array}$ & $\begin{array}{c}10 \text { years } \\
\text { old }\end{array}$ & $\begin{array}{c}9 \text { years } \\
\text { old }\end{array}$ & $\begin{array}{c}10 \text { years } \\
\text { old }\end{array}$ & $\begin{array}{c}11 \text { years } \\
\text { old }\end{array}$ \\
\hline $\mathrm{N}$ & 20 & 30 & 15 & 25 & 10 \\
\hline
\end{tabular}

Tables 2 and 3 display the distributions of the students, with respect to treatment, schools, grades, and age, respectively.
Table 3. Frequencies by gender by society

\begin{tabular}{ccccc}
\hline \multirow{2}{*}{ Gender } & \multicolumn{2}{c}{ SPRC } & \multicolumn{2}{c}{ APCL } \\
\cline { 2 - 5 } & $\begin{array}{c}\text { Naser } \\
\text { Khosrow }\end{array}$ & Shosh & Molavi & Khavarn \\
\hline Male & 10 & 11 & 16 & 16 \\
Female & 9 & 10 & 15 & 13 \\
Total & 19 & 21 & 31 & 29 \\
\hline
\end{tabular}

Table 4 provides the mean and modal scores for the eight clusters of items on the questionnaire, as well as the mean and modal score on the FEM, out of a total of 20 points, at the close of the previous school year. The data also show educational personnel have average responses of "strongly disagree," "disagree," or "neutral” for most items. The mean of students FME scores was 10.34, out of a possible 20, at the close of the previous school year, a level that allowed educational personnel to label them at-risk students with mathematical difficulties at both grade levels.

Table 4. Descriptive statistics for observed variable questionnaire

\begin{tabular}{rccc}
\cline { 2 - 4 } & Mean & Mode & $\begin{array}{c}\text { Standard Devia- } \\
\text { tion }\end{array}$ \\
\hline Reconfigure & 1.76 & 2 & 0.39 \\
Seizing & 1.64 & 2 & 0.43 \\
Sensing & 1.79 & 2 & 0.46 \\
Resource & 1.5 & 1 & 0.44 \\
Path Dependency & 2.66 & 3 & 0.5 \\
Process & 1.67 & 2 & 0.46 \\
New Innovations & 1.72 & 2 & 0.43 \\
New Process & 1.54 & 2 & 0.43 \\
Final Mathematics Examination & 10.34 & 10 & 2.59 \\
(FME) & & &
\end{tabular}

\subsection{Inferential Statistical Analyses related to Hypotheses I, II, and III}

\subsubsection{Exploratory Factor Analysis (EFA)}

The first analyses were factors analyses of the results of questionnaire responses for the questions related to whether the responses reveal evidence supporting the hypothesized structural relationships regarding dynamic capabilities and organizational inertia. An EFA (Exploratory Factor Analysis) identified eight factors in the data. Examining the literature behind the questionnaire's development and the results, these eight factors were titled, respectively: Factor 1: Sensing, Factor 2: Resource, Factor 3: Path Dependency, Factor 4: Seizing, Factor 5: Process, Factor 6: Reconfigure, Factor 7: New Process, and Factor 8: New Executed Innovations. Additional analyses follow to see if these titles are statistically justified.

\section{Confirmatory Factor Analysis of Dynamic Capabilities}

The validity and reliability values for the dynamic capability items are introduced in the nodes, factor loadings, and $t$-values in Figures 2 and 3 to examine the measurement models of dynamic capability by examining the $t$-values and the factor loadings, respectively. 


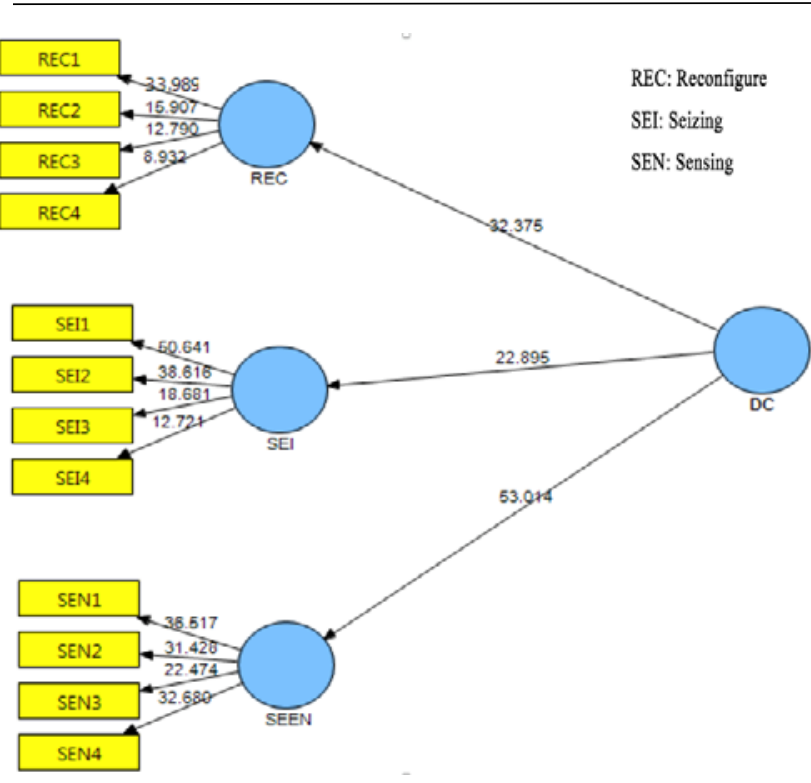

Figure 2. $t$-values of dynamic capabilities

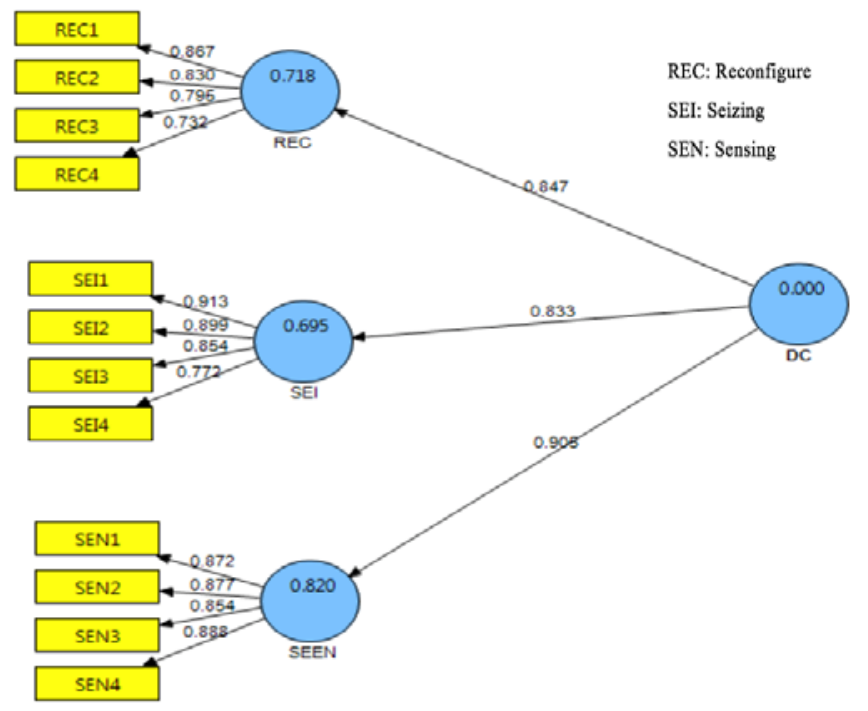

Figure 3. Factor loadings of dynamic capabilities

\section{Convergent Validity along with Reliability of Dynamic Capabilities}

The factor loadings' ranges are indicated in Table 5 in terms of items and latent variables.

Table 5. Examining the factor loadings of dynamic capabilities

\begin{tabular}{|c|c|c|c|c|c|c|}
\hline $\begin{array}{c}\text { Latent } \\
\text { Variables }\end{array}$ & Items & Loading & $\begin{array}{c}t- \\
\text { values }\end{array}$ & $\begin{array}{c}\text { Latent } \\
\text { Variable }\end{array}$ & Loading & $\begin{array}{c}t- \\
\text { values }\end{array}$ \\
\hline \multirow{12}{*}{$\begin{array}{c}\text { Dynamic } \\
\text { Capabilities }\end{array}$} & REC1 & 0.86 & 33.98 & \multirow{4}{*}{ REC } & \multirow{4}{*}{0.84} & \multirow{4}{*}{32.37} \\
\hline & REC2 & 0.83 & 15.90 & & & \\
\hline & REC3 & 0.79 & 12.7 & & & \\
\hline & REC4 & 0.73 & 8.93 & & & \\
\hline & SEI1 & 0.91 & 50.64 & \multirow{4}{*}{ SEI } & \multirow{4}{*}{0.83} & \multirow{4}{*}{22.89} \\
\hline & SEI2 & 0.89 & 38.61 & & & \\
\hline & SEI3 & 0.85 & 18.68 & & & \\
\hline & SEI4 & 0.77 & 12.72 & & & \\
\hline & SEN1 & 0.87 & 36.51 & \multirow{4}{*}{ SEN } & \multirow{4}{*}{0.9} & \multirow{4}{*}{53.01} \\
\hline & SEN2 & 0.87 & 31.42 & & & \\
\hline & SEN3 & 0.85 & 22.47 & & & \\
\hline & SEN4 & 0.88 & 32.68 & & & \\
\hline
\end{tabular}

As the Table 5 data show, the factor loadings for the dynamic capabilities' items ranged from 0.73 to 0.91 for each item and from 0.83 to 0.90 for each of the latent variables. Hence, each of the latent variables is considered as supported (Nunnally \& Bernstein, 1994). In addition, Cronbach's $\alpha$ is estimated in order to test the internal consistency of the constructs. Standards call for it to be greater than 0.70 (Cronbach, 1951). In addition, $\mathrm{R}^{2}$ is calculated in order to test the model fit. Chin (1998) introduced those three criteria for $\mathrm{R}^{2}$ : $0.19,0.33,0.67$ as poor, moderate, and good fit, respectively. In the structural equation model (SEM), the average variance extracted (AVE) is represented by the path coefficients from the observed variables to the latent variables. These values should be above 0.50 (Chin, 1998; Hair et al., 1998; Segars, 1997). Composite reliability (CR) is computed by squaring the sum of loadings and then dividing it by the sum of squared loadings plus the sum of error terms (Werts et al., 1974). A CR value of 0.70 is sufficient for research. Table 6 shows that the values of AVE, CR, $\mathrm{R}^{2}$, and Cronbach's $\alpha$ for each of the dynamic capabilities dimension constructs is greater than 0.50 . Thus, the dynamic capabilities structure for the items is considered satisfactory for continuing to check their divergent validity.

Table 6. AVE, CR, R2, and Cronbach's $\alpha$ for dynamic capabilities dimensions

\begin{tabular}{ccccc}
\hline Construct & AVE & CR & R $^{2}$ & Cronbach's $\boldsymbol{\alpha}$ \\
\hline DC & 0.52 & 0.92 & --- & 0.91 \\
REC & 0.62 & 0.88 & 0.71 & 0.82 \\
SEN & 0.76 & 0.92 & 0.81 & 0.89 \\
SEI & 0.74 & 0.91 & 0.69 & 0.88 \\
\hline
\end{tabular}

As it obvious in Table 6, for the latent variables, the AVE values are greater than 0.50 ; this is an acceptable value; and CR values are greater than 0.70 ; that is acceptable. $R^{2}$ values ranged between 0.69 and 0.71 indicating that DC has a good fit. Cronbach's $\alpha$ for each variable is greater than 0.70 . Hence, we can continue to examine the latent variables from a divergent validity standpoint as well.

\section{Divergent Validity of Dynamic Capabilities}

Cross loading is one of the methods in order to estimate of divergent validity of the EFA results. The correlations among items and latent variable serve to compare their joint structures (Henseler, Ringle, \& Sinkovics, 2009). The results of the cross loadings are shown in Table 7:

Table 7. Cross loading of dynamic capabilities dimensions

\begin{tabular}{cccc}
\hline Items & REC & SEI & SEN \\
\hline REC1 & 0.86 & 0.62 & 0.79 \\
REC2 & 0.83 & 0.41 & 0.49 \\
REC3 & 0.79 & 0.32 & 0.47 \\
REC4 & 0.73 & 0.26 & 0.35 \\
SEI1 & 0.59 & 0.91 & 0.67 \\
SEI2 & 0.52 & 0.89 & 0.63 \\
SEI3 & 0.34 & 0.85 & 0,42 \\
SEI4 & 0.29 & 0.77 & 0.32 \\
SEN1 & 0.82 & 0.65 & 0.87 \\
SEN2 & 0.49 & 0.44 & 0.87 \\
SEN3 & 0.51 & 0.51 & 0.85 \\
SEN4 & 0.52 & 0.52 & 0.88 \\
\hline
\end{tabular}

As it is shown in Table 7, correlation among items to related variables, is greater than other items and their variable by rows 
and columns, hence, it can be concluded that divergent validity is supported for the dynamic capabilities variables.

\subsubsection{Confirmatory Factor Analysis of Organizational Inertia of Child Houses}

Examining the validity and reliability of the organizational inertia of Child Houses follows the same sequence of inserting the factor loadings and $t$-values into Figures 4 and 5 . Thus, we can assess the characteristics of the measurement models for organizational inertia of Child Houses by examining $t$-values and the factor loadings, respectively.

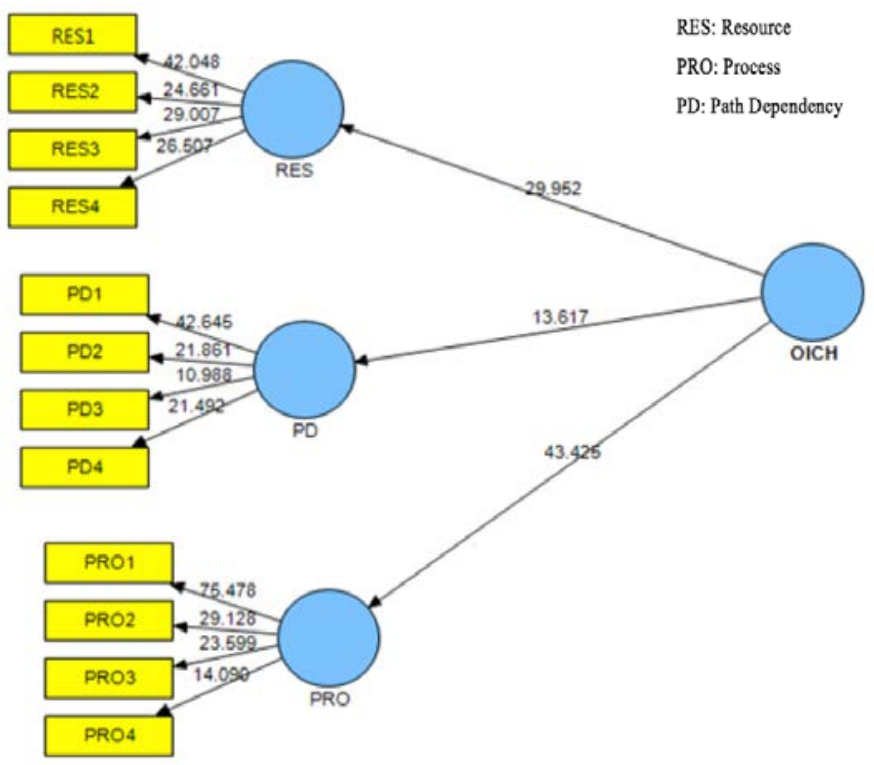

Figure 4. $t$-values of organizational inertia of Child Houses

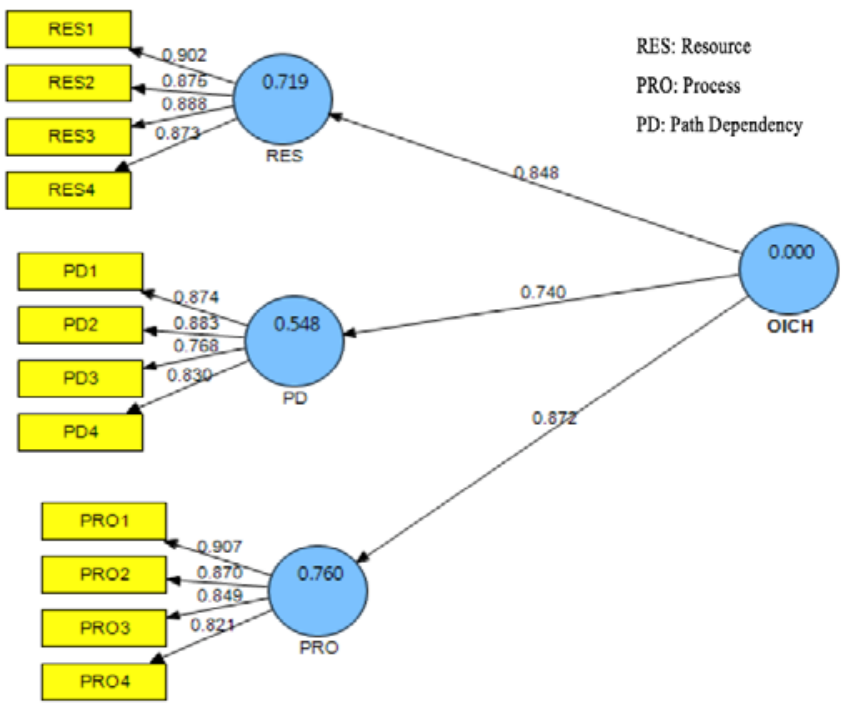

Figure 5. Factor loadings of educational inertia of Child Houses

\section{Convergent Validity along with Reliability of Organizational Inertia of Child Houses}

The factor loadings' ranges are indicated in Table 8 in terms of the items and the latent variables. As it is seen as Table 8, factor loadings of organizational inertia of Child Houses' items range among 0.76 to 0.90 for each item and among 0.74 to 0.87 for each latent variable considered as supported. In addition, $\mathrm{R}^{2}$ is calculated for the fit model, and the value there suggests that one can continue to examine the divergent validity values for the organizational validity variable.

Table 8. Examining the factor loadings of organizational inertia

\begin{tabular}{|c|c|c|c|c|c|c|}
\hline $\begin{array}{c}\text { Latent } \\
\text { Variables }\end{array}$ & Items & Loading & $t$-values & $\begin{array}{c}\text { Latent } \\
\text { Variable }\end{array}$ & Loading & $\begin{array}{c}t- \\
\text { values }\end{array}$ \\
\hline \multirow{12}{*}{$\begin{array}{c}\text { Dynamic } \\
\text { Capabilities }\end{array}$} & RES1 & 0.90 & 42.04 & \multirow{4}{*}{ RES } & \multirow{4}{*}{0.84} & \multirow{4}{*}{29.95} \\
\hline & RES2 & 0.87 & 24.66 & & & \\
\hline & RES3 & 0.88 & 29.007 & & & \\
\hline & RES4 & 0.87 & 26.5 & & & \\
\hline & PD1 & 0.87 & 42.64 & \multirow{4}{*}{ PD } & \multirow{4}{*}{0.74} & \multirow{4}{*}{13.61} \\
\hline & PD2 & 0.88 & 21.86 & & & \\
\hline & PD3 & 0.76 & 10.98 & & & \\
\hline & PD4 & 0.83 & 21.49 & & & \\
\hline & PRO1 & 0.90 & 75.47 & \multirow{4}{*}{ PRO } & \multirow{4}{*}{0.87} & \multirow{4}{*}{43.42} \\
\hline & PRO2 & 0.87 & 29.12 & & & \\
\hline & PRO3 & 0.84 & 23.59 & & & \\
\hline & PRO4 & 0.82 & 14.09 & & & \\
\hline
\end{tabular}

Table 9. AVE, CR, R2, and Cronbach's $\alpha$ of organizational inertia dimensions

\begin{tabular}{ccccc}
\hline Constructs & AVE & CR & R $^{2}$ & Cronbach's $\boldsymbol{\alpha}$ \\
\hline OICH & 0.5 & 0.92 & --- & 0.9 \\
RES & 0.7 & 0.9 & 0.54 & 0.86 \\
PRO & 0.74 & 0.92 & 0.76 & 0.88 \\
PD & 0.78 & 0.93 & 0.71 & 0.9 \\
\hline
\end{tabular}

As it obvious in Table 9, AVE is greater than 0.50; that is acceptable. CRs values are greater than 0.70 ; again acceptable values. $\mathrm{R}^{2}$ is ranged among 0.54 to 0.76 indicating $\mathrm{OICH}$ has good fit. The same holds relative to fit model for convergent validity for the latent variables associated with organizational validity.

\section{Divergent Validity of Organizational Inertia of Child Houses}

Cross loading is used to estimate the divergent validity of the EFA results shown in Table 10. Correlations between items to latent variable are shown for the hypothesized latent variables (Hensler et al., 2009). The comparison of items by cells shows that by row and by column are greater than the other values by row and column, hence supporting the divergent validity of the items to hypothesized factors for organizational inertia.

Table 10. Cross loading of organizational inertia dimensions

\begin{tabular}{cccc}
\hline Items & PD & PRO & RES \\
\hline PD1 & 0.87 & 0.61 & 0.47 \\
PD2 & 0.88 & 0.32 & 0.3 \\
PD3 & 0.76 & 0.28 & 0.25 \\
PD4 & 0.83 & 0.36 & 0.31 \\
PRO1 & 0.5 & 0.9 & 0.7 \\
PRO2 & 0.47 & 0.86 & 0.54 \\
PRO3 & 0.4 & 0.84 & 0.5 \\
PRO4 & 0.28 & 0.82 & 0.34 \\
RES1 & 0.46 & 0.7 & 0.9 \\
RES2 & 0.31 & 0.49 & 0.87 \\
RES3 & 0.34 & 0.47 & 0.88 \\
RES4 & 0.32 & 0.49 & 0.87
\end{tabular}


As it is shown in Table 10, the correlation among items to related variable is greater than other items and the variable. Then, it can be concluded that divergent validity factors are supported for the organizational inertia of Child Houses.

\subsubsection{Confirmatory Factor Analysis of Educational Performance of Child Houses}

Here, the validity and reliability coefficients for the educational performance of Child Houses are introduced at the nodes, factor loadings, and $t$-values. Figures 6 and 7 show measurement models of educational performance of Child Houses by examining $t$-values and the factor loadings respectively.

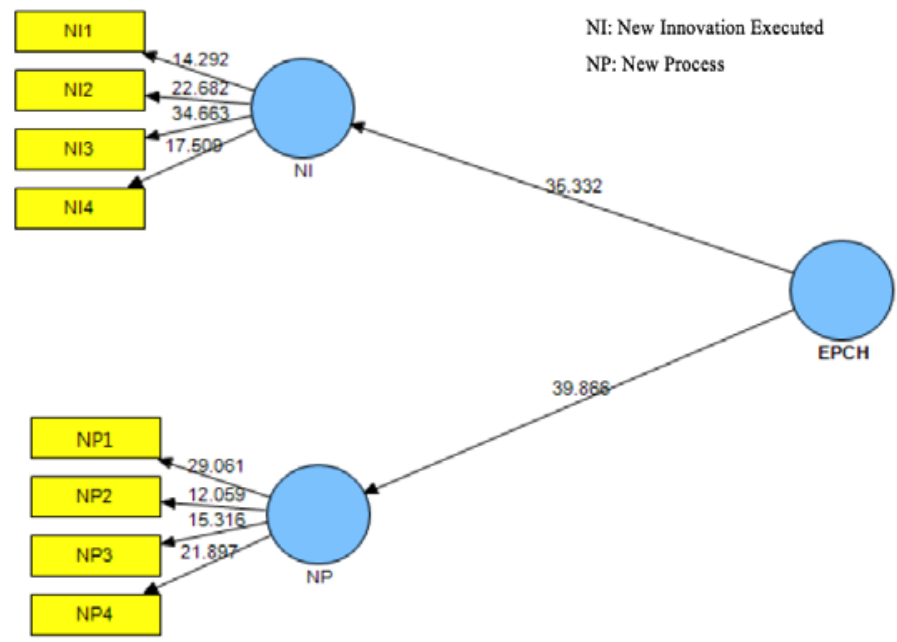

Figure 6. $t$-values of organizational performance of Child Houses

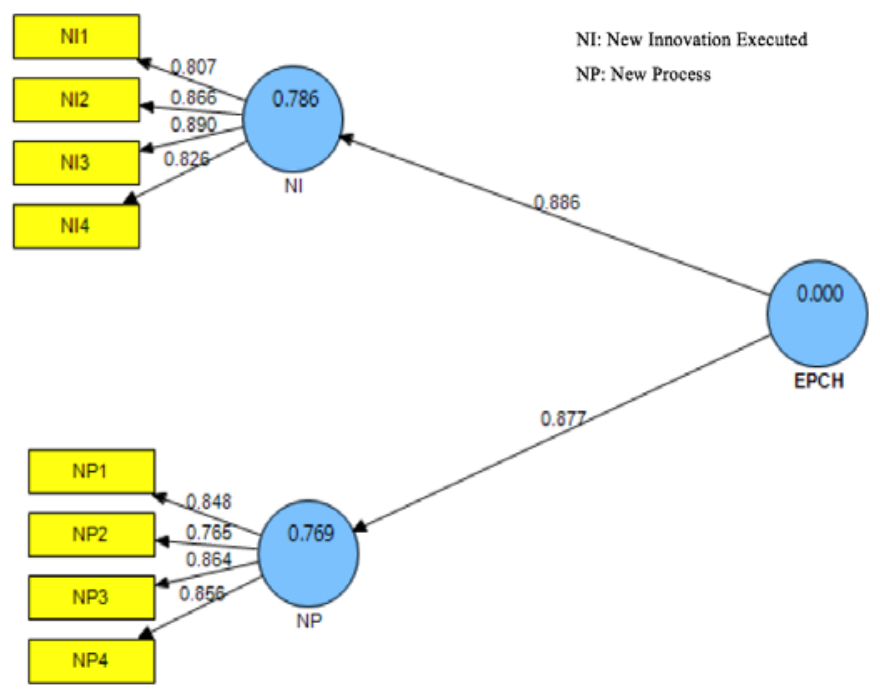

Figure 7. Factor loadings for educational performance of Child Houses

\section{Convergent Validity along with Reliability of Educational Performance of Child Houses}

The factor loadings' ranges can be seen in Table 11 in relation to the values of items and latent variables.

As it is seen as Table 11, the factor loadings for the Educational Performance of the Child Houses' (EPCH) items ranged from 0.76 and 0.89 . The factor loadings of 0.87 and 0.88 for the two latent variables NI and NP, respectively, support the factor model. In addition, Cronbach's $\alpha$ is estimated with regard to internal consistency that must be greater than 0.70 (Cronbach, 1951). In addition, $R^{2}$ is calculated in order to model fit.

Table 11. Examining the factor loadings of educational performance of Child Houses

\begin{tabular}{|c|c|c|c|c|c|c|}
\hline $\begin{array}{c}\text { Latent } \\
\text { Variables }\end{array}$ & Items & Loading & $\begin{array}{c}t- \\
\text { values }\end{array}$ & $\begin{array}{c}\text { Latent } \\
\text { Variable }\end{array}$ & Loading & $t$-values \\
\hline \multirow{8}{*}{$\begin{array}{c}\text { Educational } \\
\text { Performance } \\
\text { of the Child } \\
\text { Houses }\end{array}$} & NI1 & 0.8 & 14.29 & \multirow{4}{*}{ NI } & \multirow{4}{*}{0.88} & \multirow{4}{*}{35.33} \\
\hline & NI2 & 0.86 & 22.68 & & & \\
\hline & NI3 & 0.89 & 34.66 & & & \\
\hline & NI4 & 0.82 & 17.5 & & & \\
\hline & NP1 & 0.84 & 29.06 & \multirow{4}{*}{ NP } & \multirow{4}{*}{0.87} & \multirow{4}{*}{39.86} \\
\hline & NP2 & 0.76 & 12.05 & & & \\
\hline & NP3 & 0.86 & 15.31 & & & \\
\hline & NP4 & 0.85 & 21.89 & & & \\
\hline
\end{tabular}

Table 12. AVE, CR, R2, and Cronbach's $\alpha$ of educational performance dimensions

\begin{tabular}{ccccc}
\hline Construct & AVE & CR & R $^{2}$ & Cronbach's $\boldsymbol{\alpha}$ \\
\hline EPCH & 0.54 & 0.9 & --- & 0.87 \\
NI & 0.71 & 0.91 & 0.78 & 0.86 \\
NP & 0.69 & 0.9 & 0.76 & 0.85 \\
\hline
\end{tabular}

As it obvious in Table 12, AVE is greater than 0.50; an acceptable value. CR values are greater than $0.70 . R^{2}$ values are found 0.76 to 0.78 and that indicates EPCH has a good fit.

\section{Divergent Validity of Educational Performance of Child Houses}

Cross loading was used to estimate the divergent validity of the EFA. The correlation between items to the latent variables is indicated in Table 13 (Hensler et al., 2009).

Table 13. Cross loading of educational performance dimensions

\begin{tabular}{ccc}
\hline Items & NI & NP \\
\hline NI1 & 0.8 & 0.62 \\
NI2 & 0.86 & 0.36 \\
NI3 & 0.88 & 0.43 \\
NI4 & 0.82 & 0.42 \\
NP1 & 0.66 & 0.84 \\
NP2 & 0.29 & 0.76 \\
NP3 & 0.43 & 0.86 \\
NP4 & 0.4 & 0.85 \\
\hline
\end{tabular}

As it is shown in Table 13, the correlation between items to related variable is greater than other items in the same row or column for other items or latent variable. Thus, it can be concluded that divergent validity is supported for educational performance of Child Houses.

\subsection{Structural Equation Modeling (SEM)}

The validity and reliability of the structural model are introduced in the nodes, factor loadings and $t$-values. Figures 8 and 9 show measurement models of structural model by examining $t$-values and the factor loadings respectively: 


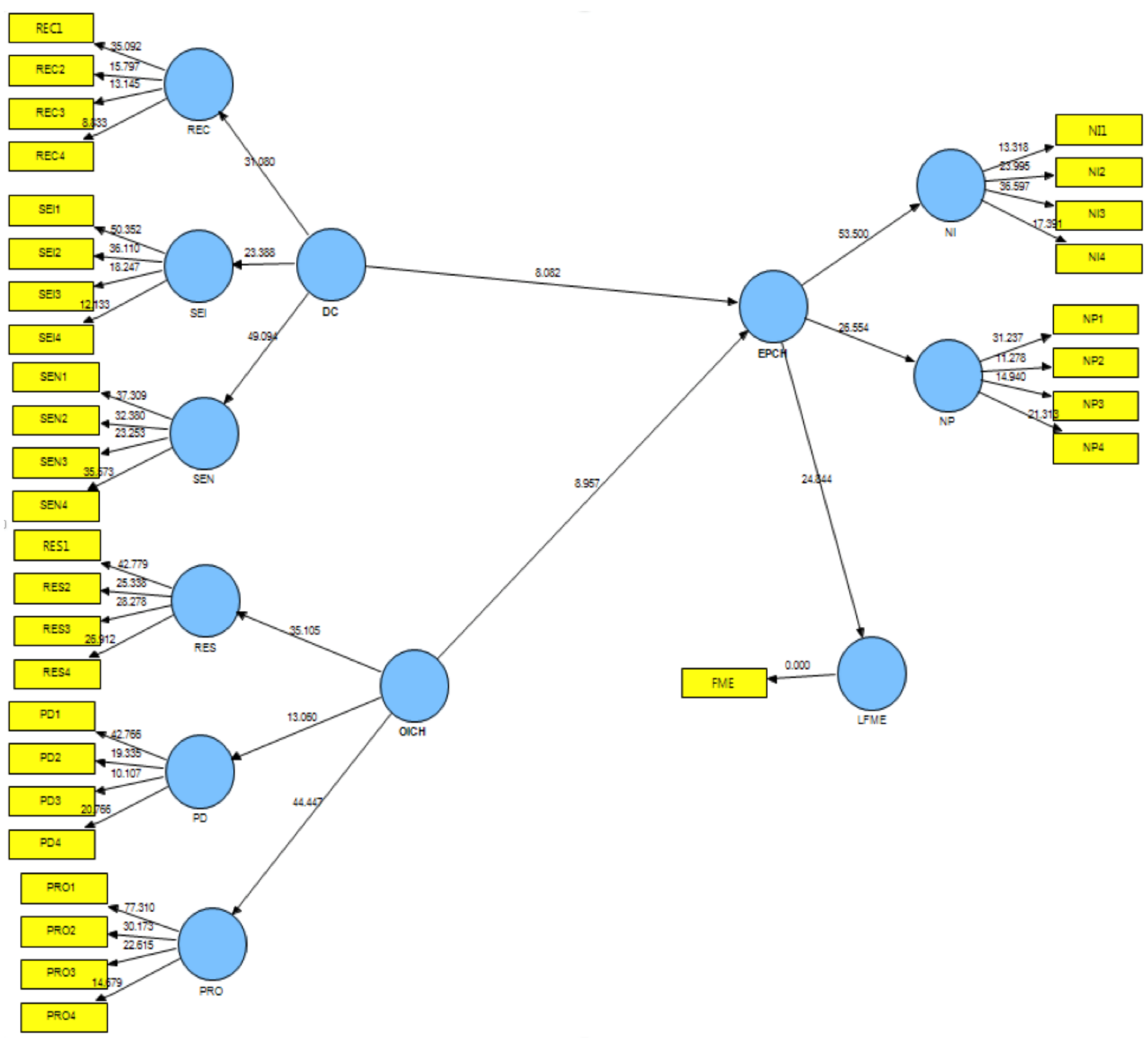

Figure 8. $t$-value of structural model

\subsubsection{Convergent Validity and Reliability of the Structural Model}

The factor loadings' ranges are indicated in Table 14 in terms of their correlations with the items and latent variables.

Table 14. Examining the factor loadings of structural model

\begin{tabular}{|c|c|c|c|c|c|c|}
\hline $\begin{array}{c}\text { Latent } \\
\text { Variables }\end{array}$ & Items & Loading & $\begin{array}{c}t \\
\text { values }\end{array}$ & $\begin{array}{c}\text { Latent } \\
\text { Variables }\end{array}$ & Loading & $\begin{array}{c}t \\
\text { values }\end{array}$ \\
\hline \multirow{8}{*}{$\begin{array}{c}\text { Structural } \\
\text { Model }\end{array}$} & RES & 0.84 & 31.08 & \multirow{3}{*}{ DC } & \multirow{3}{*}{0.51} & \multirow{3}{*}{8.08} \\
\hline & SEI & 0.83 & 23.38 & & & \\
\hline & SEN & 0.9 & 49.09 & & & \\
\hline & RES & 0.85 & 35.1 & \multirow{3}{*}{$\mathrm{OICH}$} & \multirow{3}{*}{-0.49} & \multirow{3}{*}{8.95} \\
\hline & PD & 0.72 & 13.06 & & & \\
\hline & PRO & 0.87 & 44.44 & & & \\
\hline & NI & 0.91 & 53.5 & \multirow{2}{*}{$\mathrm{EPCH}$} & \multirow{2}{*}{0.8} & \multirow{2}{*}{24.84} \\
\hline & NP & 0.84 & 26.55 & & & \\
\hline
\end{tabular}

As it is seen as Table 14, the correlations of the factor loadings of the structural models' items range between 0.72 to 0.91 for each of the items and from -0.49 to 0.80 for each of the three latent variables. Hence, the structural model for the items is supported. In addition, Cronbach's $\alpha$, being greater than 0.70 indicates there is sufficient internal consistency to proceed (Cronbach, 1951). In addition, $\mathrm{R}^{2}$ of 0.70 indicates that sufficient fit for EPCH and of 0.65 for the FME variable suggests a good model fit.

Table 15. AVE, CR, R2, and Cronbach's $\alpha$ of structural model dimensions

\begin{tabular}{ccccc}
\hline Constructs & AVE[1] & CR[2] & $\mathbf{R}^{2}$ & Cronbach's $\boldsymbol{\alpha}$ \\
\hline DC & 0.73 & 0.89 & --- & 0.91 \\
EPCH & 0.76 & 0.86 & 0.7 & 0.87 \\
OICH & 0.66 & 0.85 & --- & 0.9 \\
FME & --- & --- & 0.65 & --- \\
\hline
\end{tabular}

[1] Note: In this comparison, AVE is computed by hand, rather than by Smart PLS. [2] Note: In this comparison, CR is computed by hand, rather than by Smart PLS. 


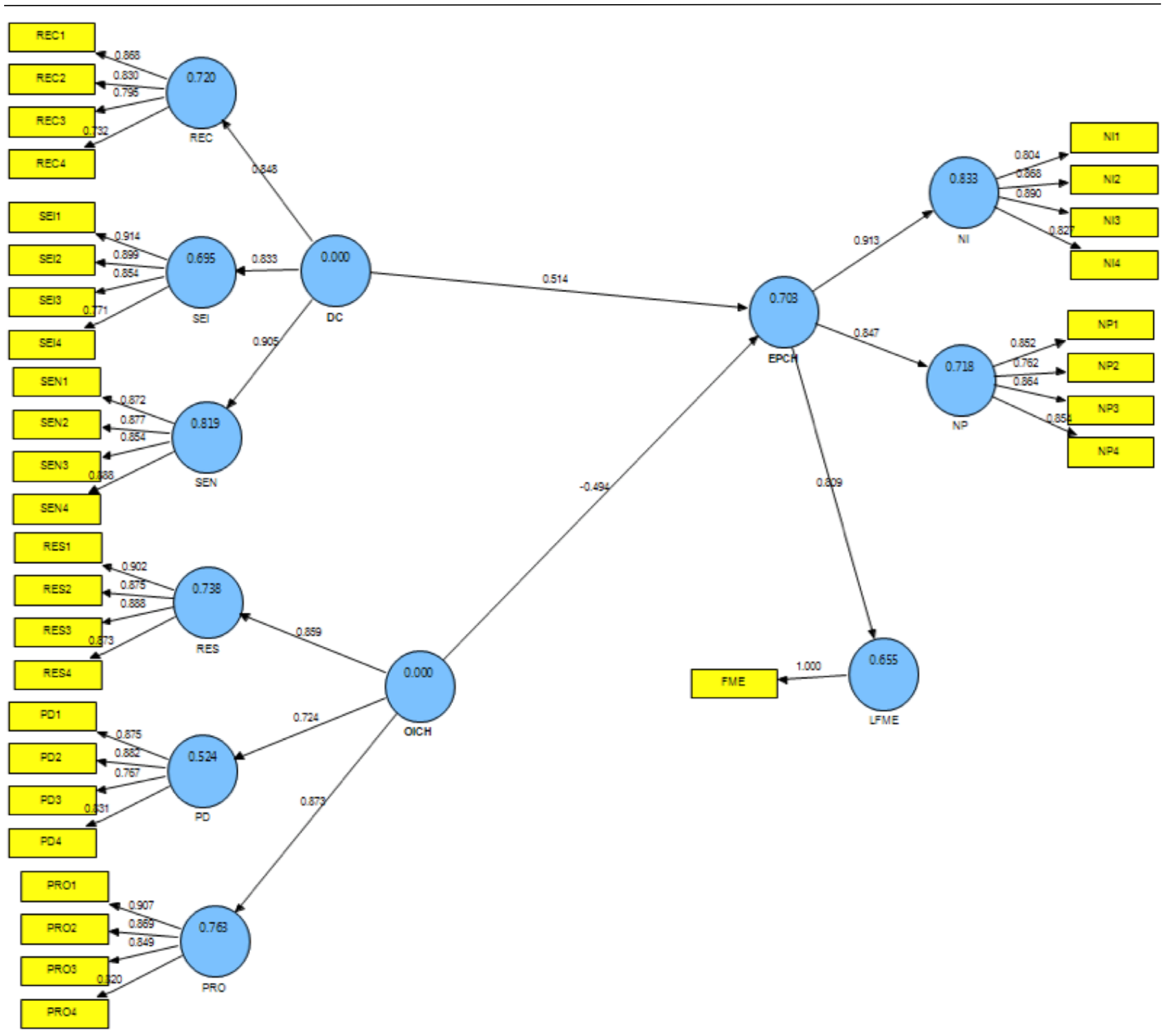

Figure 9. Factor loadings of structural model

As it obvious in Table 15, AVE is greater than 0.50; that is an acceptable value. CR values are greater than 0.70 ; again acceptable values. $\mathrm{R}^{2}$ ranges from 0.65 to 0.70 and that indicates the structural model has a good fit and hence the factors support the latent factors.

\subsubsection{Discriminant Validity of the Structural Model}

Table 16 presents the square root of AVE and the crosscorrelations using the Fornell-Larcker criterion (1981) as the approach to estimate discriminant validity. Discriminant validity is assessed to determine the external consistency of the measurement model.

Table 16. Fornell-Larcker criterion of constructs

\begin{tabular}{cccc}
\hline Constructs & DC & EPCH & OICH \\
\hline DC & 0.72 & & \\
EPCH & 0.7 & 0.73 & \\
OICH & -0.38 & -0.69 & 0.7 \\
\hline
\end{tabular}

Table 17. Fornell-Larcker criterion of item

\begin{tabular}{ccccccccc}
\hline Items & NI & NP & PD & PRO & REC & RES & SEI & SEN \\
\hline NI & 0.84 & & & & & & & \\
NP & 0.55 & 0.83 & & & & & & \\
PD & -0.27 & -0.31 & 0.88 & & & & & \\
PRO & -0.53 & -0.5 & 0.49 & 0.86 & & & & \\
REC & 0.68 & 0.42 & -0.17 & -0.34 & 0.78 & & & \\
RES & -0.6 & -0.67 & 0.41 & 0.62 & -0.4 & 0.83 & & \\
SEI & 0.57 & 0.42 & -0.09 & -0.22 & 0.53 & -0.36 & 0.86 & \\
SEN & 0.64 & 0.38 & -0.13 & -0.28 & 0.69 & -0.31 & 0.62 & 0.87 \\
\hline
\end{tabular}

The AVE value for each construct was then compared with the square of the correlation between the two constructs (Fornell \& Larcker, 1981). Tables16 and 17 display the correlations and the squared correlations with latent constructs. As the AVE values of all the latent variables were greater than the squares of their correlations, the discriminate validity was achieved and supported. 


\subsection{3 $\quad \mathrm{Q}^{2}$ Criteria of Structural Model}

Stone (1974) and Geiseer (1975) introduced conditions, which came to be known as the Stone-Geiseer criterion, to predict the capability of model. They state that models that have good fit can predict items related to "endogenous constructs" of the model. Hensser et al. (2009) determined that the following three values of $\mathrm{Q}^{2}$ : $0.02,0.15$, and 0.35 , serve as poor, moderate, and good criteria, respectively, for the value of prediction of model. The results of $\mathrm{Q}^{2}$ for the structural model dimensions are indicated in Table 18.

Table 18. $\mathrm{Q}^{\wedge} 2$ criterion of structural model dimensions

\begin{tabular}{cc}
\hline Endogenous construct & 1-SSE $/ \mathbf{S S O}=\mathbf{Q}^{\mathbf{2}}$ \\
\hline EPCH & 0.36 \\
FME & 0.69 \\
NI & 0.61 \\
NP & 0.5 \\
\hline
\end{tabular}

As it is shown in Table 18, in the column for the value of 1(SSE/SSO), the value of $\mathrm{Q}^{2}$ related to each of the constructs is greater than 0.35 . Thus, it can be concluded that the structural model has good fit.

\subsubsection{Goodness of Fit (GOF) of Structural Model}

The goodness of fit (GOF), as introduced by Tenenhaus et al. (2004), controls the fit of the general part so that the mean of communality is equal to the communality of each construct and the mean of $\mathrm{R}^{2}$ is equal to mean of the $\mathrm{R}^{2}$ of the "endogenous constructs" in the model. Wetzels, Odekerken-Schroder and Van Oppen (2009) introduced three values 0.01, 0.25, and 0.36, as poor, moderate, and good, respectively, for criteria for the GOF of the structural model. Since the value of GOF is 0.71 , one can conclude that the value GOF indicates good fit of structural model.

\subsection{Testing the Hypotheses}

The significance testing of the total effects as shown in Table 19 below was obtained by bootstrapping. The confirmation or rejection of Hypotheses I to III are also shown in Table 19.

Table 19. Study of the rejection or confirmation of hypotheses

\begin{tabular}{ccccc}
\hline Hypothesis & $\begin{array}{c}\text { Path } \\
\text { Coefficient }\end{array}$ & $\begin{array}{c}\text { t- } \\
\text { value }\end{array}$ & $\begin{array}{c}\text { Standard } \\
\text { Error }\end{array}$ & Supported \\
\hline $\begin{array}{c}\text { CD -----> } \\
\text { RECN }\end{array}$ & 0.51 & 7.81 & 0.06 & Yes \\
$\begin{array}{c}\text { IOCN ----> } \\
\text { RECN }\end{array}$ & -0.49 & 8.83 & 0.05 & Yes \\
$\begin{array}{c}\text { RECN -----> } \\
\text { EMF }\end{array}$ & 0.8 & 24.78 & 0.03 & Yes \\
\hline
\end{tabular}

The significance testing of the total effects as shown in Table 19 below was obtained by the statistical technique of bootstrapping. The path coefficients representing the hypothesized relationships between the independent moderator and the dependent variable can be seen in Table 19. For the DC -----> EPCH relationship, the empirical $t$-value has to be larger than the critical $t$-value (1.96) at a significance level of five percent $(\mathrm{p}<0.05)$. For the OICH ------> EPCH relationship, the empirical $t$-value has to be larger than the critical $t$-value (1.96) at a significance level of five percent $(\mathrm{p}<0.05)$. For the EPCH -----> FME relationship, the empirical $t$-value has to be larger than the critical $t$-value (1.96) at a significance level of five percent $(\mathrm{p}<0.05)$.

$$
\begin{gathered}
Y=\beta X \\
E P C H=\beta_{D C} X_{D C}=0.51 X_{D C} \\
E P C H=\beta_{O I C H} X_{O I C H}=-0.49 X_{O I C H} \\
F M E=\beta_{E P C H} X_{E P C H}=0.80 X_{E P C H}
\end{gathered}
$$

\section{DISCUSSION}

The analyses results indicate that the dynamic capabilities have a significant positive impact on educational performance of the Child Houses and the educational performance of Child Houses has a positive impact on FME score for at-risk students. On the other hand, the results indicate that the organizational inertia of the Child Houses has a negative impact on the educational performance of the Child Houses (two charitable societies). For dynamic capabilities, three variables are considered; reconfigure, seizing, and sensing. "Reconfigure" followed changes when educational crises have occurred. These changes include all those that have been made in educational activities and the study of whether these changes were successful. "Seizing" followed "premierships" while educational crises were occurring. "Premierships" are comprised of the creating of cooperation and self-confidence of educational personnel, creating new opportunities for innovations and cooperative working, and the implementing of modern technologies. "Sensing" followed conditions or possibilities while educational crises were occurring. These "conditions" or "possibilities" consisted of financial counterparts, improving confidence and security between members, explaining assessment instruments effectively, and selecting effective leaders among members. Whatever the educational personnel responded, it indicated that dynamic capabilities have a positive impact on educational performance of the Child Houses, in other words, whenever the quality of "reconfigure, seizing, and sensing" improved, educational performance improved and the inverse held as well. Whenever cooperation, capacity, and creating conditions merge in order to develop opportunities/conditions, changes in Child Houses will develop and flourish.

For organizational inertia, three variables are considered: entitled resources, process, and path dependency. "Resources" studied situations where and while educational events occurred. These events consisted in studying being successful in creating and nourishing educational activities, contrasting persistence on investment versus educational development, employing effective member/s, and additive investments or structured financial resources for developing new educational services. "Process" studied controlled situations where and when educational events occurred. These events contained quality of management, controlling leaders in educational change, studying the significant difference between present and previous situations, and developing new educational approaches to teaching-learning procedures. "Path dependency" studied changed situations while or where educational events occurred. These events contain developing new procedures and principles, finding connections among activities in education, accessing new skills and experiences, and joining interventions within new needed skills. 
When the educational personnel responded, it is indicated that the organizational inertia of Child Houses has a negative impact on their educational performance. In other words, whenever the status of "resources, process, and path dependency" modifies, educational performance will be improved. The first researcher has observed the performance of the two societies, both of which have the same main principles and procedures, yet it seems that there are many reasons that indicate that organizational inertia has a negative impact on the educational performance of the Child Houses. NGOs are controlled by self-managers and their governing boards. As a result, many indicators may be in a state of constant flux. In the resources section of the questionnaire, the educational personnel were asked about financial and nonfinancial resources and changes in them, as well as evaluations of such resources. The responses suggested that developments and change in them was not something the educational personnel considered often. In addition, since NGOs are often comprised of benefactors, they cannot estimate carefully budget present and future resources. They need to estimate future control and changes but they cannot do so with surety, because of the uncertainty of when such resources will arrive. This makes developing firm plans and communications difficult with past and potential funders: new board members/former teachers, education philanthropists, and the government. With the loss of such support sources, then they cannot control the selforganization's structure as a process variable of organizational inertia. Since with this loss of predication capacity among members and the external threats not controlled by them, organizations cannot sense major changes. The path dependency indicator can estimate educational performance of both Child Houses. New skills and knowledge in the path dependency section are needed to predict present and future changes. These changes were not recognizable by the educational personnel as needed factors.

For educational performance, two variables are considered entitled new innovations executed and new process. The variable "New innovations executed" observed educational services while or where educational events occurred. 'New innovations executed' was comprised of new educational services and previous educational services, workshops that were held, and marketing for recruitment of new members. "New process" was comprised of implementing new educational procedures, conducting experimental studies, finding new interventions, and bringing innovations of new educational process to the school. Based on educational personnel's responses and scores from FME of at-risk students, it is obvious that the educational performance of Child Houses has a positive impact on FME.

\section{CONCLUSIONS}

Since this research study was focused on mathematics, at the elementary level, and since at-risk students in both Child Houses were identified as students with mathematical difficulties (MD), and since their teachers and other educational personnel called them as at-risk students, it is gratifying that a factor emerges that has a significant impact on positive student performance on the FME. Further, the dynamic capabilities factor has a significant impact on the educational performance of the Child Houses. This suggests that educational performance has an impact on educational processes such as FME. If educational performance is not at a suitable level, this will result in an impact on educational intervention/s and negative results. Since at-risk students live in environment that is deprived in terms of cultural, social, financial, and educational factors, the Child House environments need to change in the directions indicated by the findings. Certainly, unsuitable educational performances led to the ignoring of primary students' main difficulties during prior grades and particularly in mathematics education.

Based on the above findings, one can argue that whenever dynamic capabilities and educational performances improved, the education of at-risk students improved. Consequently, when Child Houses have a capacity to change, organizational inertia is modified and its result will be seen in improving educational performances. It is clear that obstacles and unsolved problems in the delivery of educational services, particularly the strengthening of teaching processes led to weak performance on the part of at-risk students. The first researcher has directly observed the impact of external threats, programmatic and financial, have on educational performance and assessments, such as the FME. Other external threats directly impact the lives of the at-risk students: migration, hard work conditions, lack of proper nutrition, low literacy levels of parents, and unstable positions (financial and resources) in places such as educational centers (Child Houses) and homes can negatively impact at-risk students' educational performance or the FME. On the other hand, the lack of a strategic plan for instructional improvements based in research findings and new intervention/s can negatively impact educational performance and, consequently, students' mathematics learning in the elementary school years.

Recommendations suggest that: a) the three factors of dynamic capabilities can be implement and studied in public/special schools and these results generalized; b) the three factors of organizational inertia can be implement and studied in public/special schools and their results generalized; c) the two factors of educational performance can implemented and studied in public/special schools and their results generalized; d) the conceptual models can be developed, applied, and studied for modern interventions in the field of mathematics education for at-risk students and special students; e) the focus must be placed on more in-depth studies of the reasons for the lack of impact organizational inertia on FME; and f) more in-depth studies of the reasons for changes in the impact caused by dynamic capabilities on the educational performance of at-risk students are needed.

\section{ACKNOWLEDGMENT}

We want to express our thankfulness and appreciation to Dr. Mahdi Akbarzadeh for his help and transparency during the analysis of data with SmartPLS and the research involving other statistical issues. His information and guidance have also helped us complete this study.

\section{REFERENCES}

Amiripour, P., Dossey, J. A., Shahvarani, A., \& Tabibi, S. J. (2016). Modification of Mathematical Inertia of Elementary Special Students at Chosen Zone of Tehran through New Educational Intervention in Mathematics (Doctoral Dissertation). Science and Research Branch, Islamic Azad University, Tehran, Iran

Bakar, A. B., Tarmizi, R. A., M. Nor, S., Ali, W. Z. W., Hamzah, R. H., Samad, A. A., \& Jamian, A. R. (2010). Teachers and learners' perspectives on learning mathematics for at-risks students. Procedia Social and Behavioral Sciences, 8 , 393-402. doi:10.1016/j.sbspro.2010.12.055

Carpenter, T. P., Fennema, E., Franke, M. L., Levi, L., \& Empson, S. B. (2014). Children's Mathematics: Cognitively Guided Instruction. Portsmouth, NH: Heinemann.

Chin, W. W. (1998). The partial least squares approach to structural equation modeling. En G. A. Marcoulides (Ed.), Modern methods for business research (pp. 295-358). Mahwah: Lawrence Erlbaum. 
Cronbach, L. J. (1951). Coefficient alpha and the internal structure of tests. Psychometrika, 22(3), 297-334. doi:10.1007/BF02310555

Dobrev, S. D., Kim, T. Y., \& Carroll, G. R. (2003). Shifting gears, shifting niches: organizational inertia and change in the evolution of the U. S. automobile industry, 1885-1981. Organization Science, 14(3), 264-282. doi:10.1287/orsc.14.3.264.15163

Drnevich, P. L., \& Kriauciunas, A. P. (2011). Clarifying the conditions and limits of the contributions of ordinary and dynamic capabilities to relative firm performance. Strategic Management Journal, 32(3), 254-279. doi:10.1002/smj.882

Dyson, N., Jordan, N., Beliakoff, A., \& Hassinger-Da, B. (2015). A Kindergarten Number-Sense Intervention With Contrasting Practice Conditions for LowAchieving Children. Journal for Research in Mathematics Education, 46(3), 331-370. doi:10.5951/jresematheduc.46.3.0331

Fagnant, A., \& Vlassis, J. (2013). Schematic representations in arithmetical problem solving: Analysis of their impact on grade 4 students. Educational Studies in Mathematics. 84(1), 149-268. doi:10.1007/s10649-013-9476-4

Fletcher, M., \& Harris, S. (2012). Dynamic capabilities for internationalization: From market entry to sustainable internationalization. In Proceedings of the 39th Annual Conference of the European International Business Academy (EIBA) (pp. 1-28). Retrieved from

http://www.research.ed.ac.uk/portal/files/15017737/Dynamic_capabilities_for internationalization.pdf

Fornell, C. G., \& Larcker, D. F. (1981). Evaluating structural equation models with unobservable variables and measurement error. Journal of Marketing Research, 18(1), 39-50. doi:10.2307/3151312

Geisser, S., (1975). The predictive sample reuse method with applications. Journal of the American Statistical Association, 70(350), 320-328. doi:10.1080/01621459.1975.10479865

Gilbert, C. G., (2005). Unbundling the structure of inertia: Resource versus routine rigidity. Academy of Management Journal, 48(5), 741-763. doi:10.5465/AMJ.2005.18803920

Gilbert, C. G., (2006). Change in the presence of residual fit: Can competing frame coexist? Organization Science, 17(1), 150-167. doi:10.1287/orsc.1050.0160

Hair, J. F., Tatham, R. L., Anderson, R. E., \& Black, W. C. (1998). Multivariate data analysis. Upper Saddle River, NJ: Prentice Hall.

Hannan, M. T., \& Freeman, J. (1984). Structural inertia and organizational change. American Sociological Review, 49(2), 149-164. doi:10.2307/2095567

Henseler, J., Ringle, C., \& Sinkovics, R. (2009). The Use of Partial Least Squares Path Modeling in International Marketing. Advances in International Marketing, 20, 277-319. doi:10.1108/S1474-7979(2009)0000020014

Johnson, G. M. (1998). Principles of instruction for at-risk learners. Preventing School Failure, 42(4), 167-174. doi: 10.1080/10459889809603733

Lewis, K. E. (2014). Difference Not Deficit: Reconceptualizing Mathematical Learning Disabilities. Journal for Research in Mathematics Education, 45(3), 351-396. doi:10.5951/jresematheduc.45.3.0351

Liao, S-H. (2002). Problem solving and knowledge inertia. Expert Systems Applications, 22(1), 21-31. doi:10.1016/S0957-4174(01)00046-X

Liao, S-H., Fei, W-C., \& Liu, C-T. (2008). Relationships between knowledge inertia, organizational learning and organization innovation. Technovation, 28 (4), 183-195. doi:10.1016/j.technovation.2007.11.005

Miller, D., \& Chen, M. J. (1994). Sources and consequences of competitive inertia: a study of the U. S. Airline industry. Administrative Science Quarterly, 39, 123. doi: $10.2307 / 2393492$

Morales, K., Sanhueza, S., Friz, M., \& Riquelme, P. (2017). The Intercultural Sensitivity of Chilean Teachers Serving an Immigrant Population in Schools. Journal of New Approaches in Educational Research, 6(1).

Nedzinskas, Š. (2013). Dynamic capabilities and organizational inertia interaction in volatile environment (Doctoral Dissertation). University of Management and Economics, Vilnius, Lithuania. Retrieved from http://archive.ism.lt/bitstream/handle/1/301/ETD201344_\%C5\%A0ar\%C5\%ABnas\%20Nedzinskas.pdf?sequence=1.

Nunnally, J. C., \& Bernstein, I. H., (1994). Psychometric theory. New York: McGraw-Hill.

Powell, S. R., Fuchs, L. S., Cirino, P. T., Fuchs, D., Compton, D. L., \& Changas, P. C. (2015). Effects of a Multitier Support System on Calculation, Word Problem, and Prealgebraic Performance Among At-Risk Learners. Exceptional Children, 81(4), 443-470. doi:10.1177/0014402914563702

Segars, A. (1997). Assessing the unidimensionality of measurement: A paradigm and illustration within the context of information systems research. Omega, 25(1), 107-121. doi:10.1016/S0305-0483(96)00051-5

Stone, M. (1974). Cross valedictory choice and assessment of statistical predictions. Journal of the Royal Statistical Society, 36(2) 111-147.

Sudarshan, A., \& Maung Aye, K. H. (2008). Teacher Practices in Mathematic Classrooms with At-risk Students. In Proceedings of the Annual Meeting of the
Australian Association for Research in Education (AARE) (pp. 1-21). Retrieved from http://www.aare.edu.au/data/publications/2008/sud08417.pdf

Sull, D. N. (1999). The dynamics of standing still: Firestone Tire \& Rubber and the radial revolution. Business History Review, 73(3) 430-464. doi:10.2307/3116183

Sullivan, P., Tobias, S., \& McDonough, A. (2006). Perhaps the decision of some students not to engage in learning mathematics in school is deliberate. Educational Studies in Mathematics, 62(1), 81-99. doi:10.1007/s10649-006-1348-8

Sydow, J., Schreyogg, G., \& Koch, J. (2009). Organizational path dependence: opening the black box. Academy of Management Review, 34(4), 689-709. doi:10.5465/AMR.2009.44885978

Teece, D. J., (2007). Explicating dynamic capabilities: the nature and micro foundations of (sustainable) enterprise performance. Strategic Management Journal, 28(13) 1319-1350. doi:10.1002/smj.640

Teece, D. J., Pisano, G., \& Shuen, A. (1997). Dynamic capabilities and strategic management. Strategic Management Journal, 18(7) 509 - 533. doi:10.1002/(SICI)1097-0266(199708)18:7<509::AID-SMJ882>3.0.CO;2-Z

Tenenhaus, M., Amato, S., \& Esposito Vinzi, V. (2004). A global goodness-of-fit index for PLS structural equation modeling. In Proceedings of the 42nd Scientific Meeting of the Italian Statistical Society (SIS) (pp. 739-742). Padova: CLEUP.

Tosun, T. (2000). The beliefs of preservice elementary teachers toward science and science teaching. School Science and Mathematics, 100(7), 74-379. doi:10.1111/j.1949-8594.2000.tb18179.x

UN (2016). Human Rights Commission's Committee on the Rights of the Childs Convention (Report). Retrieved from http://www.ohchr.org/EN/HRBodies/CRC/Pages/CRCIndex.aspx

Vatter, T. (1992). Teaching mathematics to the at-risk secondary school student Mathematics Teacher, 85(4), 292-94.

Wehlage, G. G., \& Rutter, R.A. (1986). Dropping out: How much do schools contribute to the problem? Teachers College Record, 87(3), 374-392.

Wernerfelt, B. (1984). A resource-based view of the firm. Strategic Management Journal, 5(2), 171-180. doi:10.1002/smj.4250050207

Werts, C. E., Linn, R. L., \& Joreskog, K.G. (1974). Intraclass reliability estimates: Testing structural assumptions. Educational and Psychological Measurement, 34(1), 25-33. doi:10.1177/001316447403400104

Wetzels, M., Odekerken-Schroder, G., \& Van Oppen, C. (2009). Using PLS path modeling for assessing hieratical construct models: Guidelines and Empirical Illustration. MIS Quarterly, 33(1), 177-195.

Zahra, S. A., Sapienza, H. J., \& Davidsson, P. (2006). Entrepreneurship and dynamic capabilities: A review, model and research agenda. Journal of Management Studies, 43(3), 917-955. doi:10.1111/j.1467-6486.2006.00616.x

Zott, C. (2003). Dynamic capabilities and the emergence of intra-industry differential firm performance: Insights from a simulation study. Strategic Management Journal, 24(2), 97-125. doi:10.1002/smj.288

\section{NOTES}

${ }^{1}$ Note: The first author interviewed all personnel (in both societies) with respect to their opinions about the factors involved in the educational environment and environmental situations that lead to academic failure of at-risk students. It seems that at- risk students who have mathematical difficulties (MD) may also have difficulty in the reading of mathematical problems (in literature), or stating the related stories, and other affairs that are related to MD such as unsuitable conditions in the home and work place.

ii Note: The researcher has intended the study to focus on previous performance of mathematics among all at-risk students. Then FMEs are considered as previous performance (general performance of mathematics throughout math book).

\section{How to cite this article:}

Amiripour, P.; Dossey, J.A. \& Shahvarani, A. (2017). Impact of Organizational Inertia and Dynamic Capabilities on Educational Performance of the Charitable Societies and Its Impact on Mathematical Performance of Elementary At-Risk Students. Journal of New Approaches in Educational Research, 6(1), 37-49. doi: 10.7821/naer.2017.1.199 